\title{
The paradox in international cooperation: Institutionally embedded universities in a global environment
}

Eric Beerkens · Marijk van der Wende

Published online: 20 April 2007

Springer Science+Business Media B.V. 2007

Erratum to: High Educ 53(1): 61-79

DOI: $10.1007 / s 10734-005-7695-z$

The last author's name was misrepresented in the online metadata of the article and in the printed version of Higher Education Volume 53(2007), No. 1, p. 61. 